\title{
'Rights Talk' in Europe: The Influence of Rights Talk, American Style, on Danish Democracy and Welfare
}

\section{Helle Porsdam}

University of Southern Denmark

"America," wrote Margaret Atwood in her famous 1972 novel Surfacing, is "what's in store for us, what we are turning into." Americans "spread themselves like a virus, they get into the brain and take over the cells and the cells change from inside and the ones that have the disease can't tell the difference." As a Canadian with American ancestors, Atwood was speaking from an elsewhere that knew its enemies to be close by and, to a certain extent, already internalized. The theme of America as a harbinger of universal trends and developments has been an important one in her work ever since. When she was asked about her choice of genre for that other famous novel about abortion, The Handmaid's Tale (1985), whose action is set in the Northeastern part of the United States and whose historical motifs are in every respect American, she answered that she thought of her new novel as "a walking along of a potential road, and the reader as well as the writer can then decide if that is the road they wish to go on. Whether we go that way or not is going to be up to us."2

While I do not share Atwood's antagonistic attitude vis-à-vis the

1. Margaret Atwood, Surfacing (N.Y.: Fawcetl Crest, 1972), 153.

2. Atwood, quoted in Cathy N. Davidson, "Feminist '1984': Margaret Atwood Talks about Her Exciting New Novel," M.S., February 1986, 25. 
United States, I do agree with her view of America as a vast human laboratory that may well hold the key to what is in store for us in the rest of the Western world. I too think America is a trendsetter, and that we would do well to observe this human laboratory from a - critical - distance so as better to be able in the end to decide "whether to go that way or not." The particular "way" that is the focus of this article is the centrality in American culture and politics of law and of a legalistic vernacular, aptly termed "rights talk" by Mark Tushnet and Mary Ann Glendon. ${ }^{3}$ The current favorite pastime of "lawyer-bashing" testifies to the ambivalence most Americans feel toward lawyers, but when things come to a head it is to jurists, rather than to politicians or even members of the clergy, that Americans typically turn in their search for answers. In the U.S., as Mary Ann Glendon once wrote, "discourse about rights has become the principal language that we use in public settings to discuss weighty questions of right and wrong." 4

As we Scandinavians watch one American movie or television series after another or listen to the news coming out of the U.S., we may well wonder at the way in which Americans look to their courts to pronounce the norms for many relationships and seem to consider justice as much "a mechanism for community debate and civic instruction as for redressing legal wrongs." It will be argued here, however, that American tendencies toward formulating and defining issues - be they of a political, social, moral, or cultural nature - in terms of rights are coming our way. As we are becoming more international/global and therefore also more culturally heterogeneous, we too are becoming more aware of our rights and are beginning to turn to our lawyers and courts for help.

Whereas before February 1999 - that is before the Danish Supreme Court for the first time ever asserted its right to judicial review - we Danes used to think and believe that, as one of our famous $19^{\text {th }}$ century politicians put it, "there is no one above or beside the Danish Parlia-

3. Mark Tushnet, “An Essay on Rights," Texas Law Review 62.8 (May 1984); Mary Ann Glendon, Rights Talk: The Impoverishment of Political Discourse (N.Y.: The Free Press, 1991).

4. Glendon, Rights Talk, x. On the role of law in American culture and society, see also my own Legally Speaking: Contemporary American Culture and the Law (Amherst, MA: University of Massachusetts Press, 1999).

5. Geoffrey C. Hazard and Michele Taruffo, American Civil Procedure (New Haven, CT: Yale University Press, 1993), 211. 
ment," ${ }^{, 6}$ we now know that we have a Supreme Court that is ready to be active when the need arises. We have seen within the past few years, cases of a different - and in a Danish context unusual - kind reach our courts; cases in which essentially moral/religious and/or political issues get to be settled not in the political, but in the legal arena. And we have witnessed a number of changes within the legal profession itself changes that concern the way in which judges are selected and appointed and the way in which law firms operate.

This politicization of the legal arena - courts and their legal personnel being drawn further and further into political, economical, and cultural life - seems to be accompanied, furthermore, by a legalization of political life. The past decade or so has seen a growth in the use of courts to challenge decisions of local and central government, for example, just as there has been a tendency to inject a rights discourse into the moral and political debate. One recent example of this latter tendency is the way in which certain organizations for the protection of disabled people, frustrated by what one of their leaders, Judge Holger Kallehauge, has called "the politics of good intentions" - that is, the traditional pressure and negotiation modes of influencing Danish public policy - have now turned their attention toward the possibility of taking legal action.

Swedish political scientist Torbjörn Vallinder has referred to these kinds of developments as "the judicialization of politics" "; others have talked about a "juridicalization of politics." As Vallinder sees it, the judicialization of politics does not only take place in the Western world. It is a world-wide phenomenon that originated with the United States emerging as the democratic superpower after the Second World War whose

6. This remark is attributed to Viggo Hørup, a major Danish politician of the late $19^{\text {th }}$ century.

7. Holger Kallehauge, "Handicap og menneskerettigheder," LighedsTegn, No. 3, 1998, 3.

8. See Torbjörn Vallinder, "The Judicialization of Politics - $\Lambda$ World-wide Phenomenon: Introduction," International Political Science Review (1994), Vol. 15, No. 2, 91-99. See also The Global Expansion of Judicial Power, edited by C. Neal Tate and Torbjörn Vallinder (N.Y.: New York University Press, 1995), chs. 1 and 2. - In this latter work, Vallinder offers this definition: "Thus the judicialization of politics should normally mean either (1) the expansion of the province of the courts or the judges at the expense of the politicians and/or the administrators, that is, the transfer of decision-making rights from the legislature, the cabinet, or the civil service to the courts or, at least, (2) the spread of judicial decision-making methods outside the judicial province proper. In summing up we might say that judicialization essentially involves turning something into a form of judicial process" (13).

9. See e.g. Martin Shapiro, "Juridicalization of Politics in the United States," International Political Science Review (1994), Vol. 15, No. 2, 101-12. 
political system became an ideal to be emulated. It has since been reinforced by the efforts of various international organizations in defence of human rights and, perhaps most importantly, by the European Convention for the Protection of Human Rights (signed November 1950 and entered into force in September 1953), as upheld by the European Court. Since the European Convention came into existence, the parliaments of the various European countries have had to amend legislation pertaining to the rights of citizens. Most recently, we have witnessed the incorporation into British law of the European Convention - an incorporation that has carried with it enormous challenges for British common law.

At one level, this essay is about the dynamics of cultural transfer. At another, it is about the political impact on Danish society of the spreading of American legal culture. Whereas formerly scholars within both the humanities and the social sciences considered cultural transfer a one-way street - the dominant or dominating culture spreading its cultural "messages" to others who would passively (and more or less grudgingly) absorb it - most scholars would argue today that "victims" of cultural transfer sometimes succeed in using the cultural input they receive for their own ends. What have been and what will most likely in the future be the effects on Danish society of a spreading of rights discourses, American style? Has the spreading of rights talk brought about a transfer of policy-making power to the courts? What are the internal, Danish factors that have been at work here? Are there examples of the Danes attempting to "Danify" rights discourses? In attempting to come up with an answer to these questions, I hope to be able to pave the way for a discussion about "whether we go that [American] way or not."

\section{The Dynamics of Cultural Transfer}

The dynamics of cultural transfer is a rapidly growing field of inquiry. In the last ten to fifteen years, the focus of influence studies seems to have changed: one-directional pursuits that see cultural influence as simply a linear transmission of impulses in which the receiving end remains more or less passive have been replaced by inquiries into what is perceived as processes of cultural transfer, interpretation, and interaction. Emphasizing 
the difference between the social and cultural contexts of sender/producer and receiver, historians, ethnographers, social anthropologists and others increasingly focus on how transnational cultural flows change in different national contexts. In relation to the cultural influence of the United States, cultural critics and others have, as Elisabeth Herion Sarafidis argues, "increasingly moved away from the discussion of the impact of American products and ideas on Europe, away from one-dimensional discussions of 'influence,' and instead focused on what might be called the contact zone, arguing that the question of American influence is more complex and multifaceted than has generally been recognized."10

Along with the other Scandinavian countries, my native Denmark has been fairly receptive to American cultural influences in the post-war period; yet, the American culture of rights has not simply been transplanted wholesale. "Rights may," as Manfred Berg and Martin H. Geyer put it, "be '[the most] universal feature of politics in the late twentieth century,' but national traditions seem to remain very strong in shaping the particular 'set of beliefs and values' that make up a culture of rights." 11 The two German historians are talking about Germany here, but what they say about the cultural transfer of a rights culture applies just as much to Denmark, especially since some of the American rights influence comes to us via Germany. The American insistence after the Second World War on a rights-based constitutional structure in the Federal Republic of Germany has been instrumental in Germany's Constitutional Court (the Bundesverfassungsgericht) becoming as fierce a guardian of human rights as the U.S. Supreme Court has been of the Bill of Rights. ${ }^{12}$ The decisions of the Bundesverfassungsgericht have had a major impact

10. Elisabeth Herion Sarafidis, "Reflections on the Dynamics of Cultural Transfer," Sinas-News, No. 26, 2001,3 .

11. Manfred Berg and Martin H. Geyer, "Introduction", in Berg and Geyer, eds., Two Cultures of Rights: The Quest for Inclusion and Participation in Modern America and Germany (German Historical Institute, Washington D.C. and Cambridge: Cambridge University Press, 2002), 15-16.

12. Historians Geir Lundestad and Beate Neuss have written extensively on the role played by the United States in creating the European Union. See Lundestad, The American "Empire" and Other Studies of US Foreign Policy in a Comparative Perspective (Oxford University Press and Norwegian University Press, 1990) and "Empire" by Integration (N.Y.: Oxford University Press, 1998); and Neuss, Geburtshelfer Europas? Die Rolle der Vereinigten Staaten im europäischen Integrationsprozess 1945-1958 (Baden-baden: Nomos, 2000). On the American influence on rebuilding Germany into a constitutional democracy see Shirley Williams, "Human Rights in Europe" in Samantha Power and Graham Allison, eds., Realizing Humam Rights: Moving from Inspiration to Impact (N.Y.: St. Martin's Press, 2000), 77-109. 
on the evolution of human rights law in Europe. Danish lawyers and judges study these decisions with great interest.

The internal political and cultural discussions that are of particular importance in this connection and in which the American rights influence plays a role, are current discussions about the welfare state. ${ }^{13}$ Even though most Danes would probably say that it is exaggerated to use the word "crisis" in connection with the Danish welfare model, the taxfinanced welfare state as we have known it for the past generation or two seems to be undergoing certain important changes. The election in November 2001 made it clear that the majority of the Danish electorate has moved to the right. The coalition government headed by the Social Democrats was dethroned in favor of a more right-of-center government, whose declared goal is to privatize parts of Danish welfare. Danes, it would seem, tend to look around for useful alternatives, and it is highly likely that one such useful alternative comes to us from the United States.

In the classic version of Danish and Scandinavian welfare democracy, welfare services and benefits have not been considered "rights," just as the constitution has not been regarded as an important instrument in securing welfare rights. Danes have typically looked to the state for the maintenance of a social safety net, comprising everything from comprehensive social security to free education, public day-care for children and services for the elderly and people with disabilities. The allocation of benefits and services has taken place according to the principle of universalism, that is, individually to all members of society regardless of need. Understood broadly as "a shared political ideology represented by most political forces in the Nordic countries rather than just by social democratic or labour parties," as Martin Scheinin sums it up, social democracy "has contributed to the systematic development of a large public sector which through democratic decision-making takes care of such services and distribution decisions that in many other countries are left to the market mechanism or otherwise to private actors." 14

13. American historian Richard Pells has argued that European discussions of Americanization very often play a role in whatever internal political and cultural discussions a particular country is currently witnessing. See Richard Pells, Not Like Us: How Europeans Have Loved, Hated, and Transformed American Culture Since World War II (N.Y.: Basic Books, 1997).

14. Martin Scheinin, "Introduction," in Martin Scheinin, ed., Welfare State and Constitutionalism-Nordic Perspectives (Copenhagen: Nordic Council of Ministers, 2001), 20. 
Though clashing in several important respects with this classic version of Danish welfare democracy, American constitutional democracy is beginning to look more attractive to many Danes. Danish lawyers and academics see a transfer of power from politics to law, from parliament to courts, and they note that Danes currently seem to attach more weight and more expectations to the notion of rights than they used to. To the general public, of course, the introduction to American constitutional democracy mainly happens via television series and movies. Danes watch a fair number of U.S.-made productions, and the daily dose of American popular culture - and perhaps especially American popular legal culture - reminds us that there is a different way of doing things out there. With their many rights claims and political arguments in favor of individual autonomy, American legal television series like Judging Amy, Ally McBeal, The Practice, Philly, and Law and Order and films such as A Few Good Men (1992), Philadelphia (1993), and A Civil Action (1998) are attractive to Danes who wonder about the ever-increasing size of Danish bureaucracy and government regulation.

\section{From "Democracy Without" to "Democracy With Constitutionalism"}

The 1999-case that gave us judicial review in Denmark, concerned public funding for certain Danish schools, the so-called "Tvind" schools. When the Minister of Education persuaded a majority of the Danish parliament to support a bill that proposed to cut off funding to some of these schools, one of them sued the Minister. The case eventually reached the Danish Supreme Court that found for "Tvind," thus for the first time ever declaring a bill unconstitutional. The "Tvind"-case, as it came to be known, never received as much attention as it should have. Danish politicians virtually welcomed the decision - now, they said, the Danish Supreme Court had adapted to legal and political developments in neighboring European countries. As for Danish lawyers and law professors, most of them tended to believe that this case would not automatically lead to more activist courts. The Supreme Court had simply taught Parliament a lesson about the separation of powers. Only one or two lawyers 
saw this event as something extraordinary. One of them is Hjalte Rasmussen, a professor of law at the University of Copenhagen. He has argued in various publications that Danish democracy is currently undergoing certain changes; most importantly, we are heading toward what he calls "democracy with constitutionalism." Ever since the parliamentary system was established in the early $20^{\text {th }}$ century, Danes have lived within a democracy without constitutionalism - meaning a democracy without judicial control of the legislative branch. We do have a written constitution (indeed we just celebrated its $150^{\text {th }}$ anniversary in 1999), but it has been left to elected politicians in the parliament to interpret our constitution - even those parts of the constitution that lay down limits for the parliament's own legislative powers. That is in itself problematic; but perhaps even more problematic is the (potential) lack of security for minorities. In a democracy without constitutionalism, minorities will have to rely on the good will and the consensus of the majority. If minorities are not successful in persuading the majority that their particular needs are important here and now, then they have to subject themselves to the will of the majority. In the worst case we will get what Rasmussen calls "an enlightened majority dictatorship."15

As long as there is a reasonable degree of consensus in Denmark about important political, social, and cultural issues, this situation is tolerable. But this could very well change. As a result of our membership in the European Union and global tendencies as a whole, we do increasingly have to open our borders to foreigners. The Danish people may not like it, but we too will become more multicultural - and we too will have to learn to put up with a political situation that does not allow for consensus. The core of democracy with constitutionalism, says Rasmussen, is judicial review. The best way to protect the interests of minorities is by allowing the courts to be more judicially activist (that is, to make use of judicial review). Our constitution lists a whole number of basic rights and we should not allow the majority to conveniently "forget" about these rights.

It is especially when we are talking about human rights that the importance of judicial review is emphasized, according to Rasmussen. The

15. Hjalte Rasmussen, Folkestyre, Grundlov og Hojesteret: Grtundlovens $\$ 20$ på prove (Copenhagen: Christian Ejlers' Forlag, 1996), 38. 
argument in favor of securing the interests of minorities is most powerful when it comes to cases involving human rights. And here, Denmark, along with our neighbouring countries, has signed all sorts of treaties and conventions that increasingly make it clear that regardless of what the population might think, there are certain basic rights that we have to extend to e.g. asylum seekers and immigrants. Most importantly, in 1992 we incorporated into Danish law the European Convention for the Protection of Human Rights and Fundamental Freedoms. Ever since, we have seen what another Danish lawyer, Jens Elo Rytter, calls a "rights evolution" in Denmark. Things have happened slowly (hence this has not been a rights "revolution"), but surely - to the point where today, "no lawyer, judge, or civil servant who deals with criminal law, social law, family law, administrative law, labor law, and the status of aliens can avoid taking into consideration basic individual rights - as these are laid down in the European Convention for the Protection of Human Rights and Fundamental Freedoms and the Danish Constitution and are still being expanded as a result of what is happening in the European Court of Human Rights."16

Along with the tendency toward more activism on the part of the Danish courts, we have witnessed a number of changes within the legal profession itself. Judges who used before July 1999 to be appointed by the Ministry of Justice are now appointed by an independent committee one of whose declared goals it is to create a politically, socially, and culturally more diverse body of judges than we have hitherto seen. Among the latest appointees to the Danish Supreme Court are a former attorney, who has often been in the media speaking up for the rights of the weaker members of society, and the former president of the Danish bar association - neither is the civil servant or grey eminence type of judge typically appointed only a few years ago.

Following the growth in international business transactions and relationships, moreover, a number of mergers have taken place between law firms so that today some of the largest law firms in Denmark count as many as seventy-five lawyers - not much, perhaps, by comparison to some of the largest American law firms, but a far cry from the one-person

16. Jens Elo Rytter, "Rettighedsevolutionen i dansk ret," Lov og ret, no. 4, 2000, 14 (my translation). 
law firm of old. What we have seen within the past few years, furthermore, are cases of a different kind reach the Danish courts; cases in which essentially moral/religious and/or political issues get to be settled not in the political, but in the legal arena. One interesting example is the so-called "Headscarf case" from 1999 - a case concerning the right of a second-generation Danish woman of Muslim faith to wear a headscarf to work. Ostensibly about freedom of speech and expression, this was a case that had a strong element of identity politics about it too. The plaintiff, Islam Amin Baktyar, won - the department store "Magasin" had to change its dress code and to pay Baktyar $10.000 \mathrm{kr}$.

A second example is a case about the constitutionality of the government's withdrawal of funding for unemployed people who refuse to go on the job market. It is currently pending and was brought by Attorney Christian Harlang who explicitly wants to challenge the Danish Supreme Court on Article 75 of the Danish Constitution - an article which has been considered in the past to merely signal a political wish to provide some level of welfare to the Danish people and not a concrete legal right. If Harlang wins this case, then we can truly talk about a shift from consensus politics to rights; then Danish welfare has become a question of rights for the judiciary - rather than for the legislature - to decide!

These cases - and others like them - would not have been brought fifteen years ago. They are very different; yet, the people responsible for bringing them share a basic wish to have the courts - and not just the legislature - speak to the issue of the welfare, physical as well as mental, of the Danish people. The combination of identity politics, welfare and rights is something we know well from the U.S.; in a Danish context, the courts will be entering virgin territory.

\section{Mediation - Rights Talk, Danish (or Scandinavian) Style?}

As mentioned above, the dynamics of cultural transfer has been of great interest these past few years to a number of researchers from both the social sciences and the humanities. I want to end this essay by drawing attention to a phenomenon that I see as a Danish attempt to deal with cultural input from the United States in such a way that it becomes manage- 
able and acceptable. I am thinking here of mediation or alternative dispute settlement.

The interest in alternative dispute settlement has gone up within the past few years. At the University of Copenhagen, courses in mediation are very popular with students - so popular, in fact, that members of the university's law school faculty have created a new two-year part-time Master's degree in Mediation and Conflict Resolution. The aim of the program is "[to provide] students with a solid theoretical and practical foundation for acting as third-parties in conflicts in a constructive and professional manner" and "to give students an overall understanding of conflict by combining conflict on a personal and individual level with conflict on a societal level."17 The program opened in the fall of 2002 and has gotten off to a very promising start.

Throughout Denmark, moreover, various attempts have been and are currently made to settle disputes via mediation. Over the past year, lawyers at the county level have experimented with offering mediation to parents in divorce cases. The experiment seems to have been a success. Approximately 70 percent of the attempts at mediation have resulted in conflict resolution. Following this success, as of January 1, 2003, five Danish city courts are offering legal mediation on an experimental basis in all civil law areas. The idea is to offer parties involved in a civil law suit free mediation so that they may avoid a lengthy and costly trial in a court of law. The mediation will be done by judges and lawyers, who have been preparing themselves by taking special courses in conflict resolution. In two years, the experiment will be assessed, and if it turns out to have been a success, then legal mediation will be elevated into law and thereby made available to all Danes involved in a civil law suit.

In its modern form, the inspiration of alternative dispute settlement comes to us from the U.S. However, there has always been a strong tradition in Denmark of mediation and arbitration; indeed, Danes and other Scandinavians seem to have brought this tradition with them when they emigrated to the U.S. As historian Jerold Auerbach has told us, in the

17. This information is available at www.jur.ku.dk/konfliktmaegling. According to Project Director Lin Adrian, there were 78 applicants for 26 places in the fall of 2002 . For the 40 places available to law students in the 2003 spring course on mediation and conflict resolution at the Copenhagen Law School, moreover, 120 students have signed up. 
immigrant communities of the New World, mediation was considered a genuine alternative to legal dispute settlement. ${ }^{18}$ For the typical immigrant, the legal way of doing things marked too individualistic an approach to dealing with life. Mediation was less confrontational and more community oriented. As time went by, mediation ended up being done by lawyers, thereby loosing some of its alternative nature. It is still less confrontational and adversarial, however, and this may well be one of the reasons for its popularity with the Danish public. Alternative dispute settlement combines something familiar (consensus politics) with something new and different (legalization). Ultimately, mediation may be one - prominent - Danish way of "doing" rights talk; it may be one of the national traditions that have, as Berg and Geyer put it, "seem[ed] to remain very strong in shaping the particular 'set of beliefs and values' that make up a culture of rights." 19

18. See Jerold S. Auerbach, Justice Without Law? Resolving Disputes Without Lawyers (N.Y.: Oxford University Press, 1983), chapters 3 to 5.

19. See note 8 . 